\title{
KEPUASAN PETANI TERHADAP LAYANAN PASAR LELANG CABAI SIDO DADI DI KABUPATEN KULON PROGO
}

\author{
Rahmi Dwi Agustin, Agus Dwi Nugroho*, Masyhuri \\ Program Studi Ekonomi Pertanian dan Agribisnis Fakultas Pertanian Universitas Gadjah Mada \\ Jl. Flora, Bulaksumur, Karang Malang, Caturtunggal, Depok, Sleman, Yogyakarta 55281 \\ *Corresponding author: agus.dwi.n@mail.ugm.ac.id
}

\begin{abstract}
One of the Sido Dadi auction market weaknesses is delay payment system to farmers. This system is done by waiting for payment from the merchant if the chili has been completely sold. This situation causes farmers to be dissatisfied with the auction market services. This study intended to determine the level of farmer's satisfaction to the Sido Dadi auction market services and its determinant factors. This research was conducted at the Sido Dadi auction market because it was the first auction market in Galur District, Kulon Progo Regency, Yogyakarta Province. The number of respondents was 60 farmers chosen by purposive sampling. The Customer Satisfaction Index (CSI) and regression used to analyze the data. The results showed that farmers were satisfied with the auction market services. The determinant factors of farmer's satisfaction are age, education level, and land area. Farmer satisfaction is in line with increasing of farmers' age but in contrast to education and the farmer's land area. The Sido Dadi auction market needs to use of the contribution funds to complement infrastructure and held human resource development training. The auction market also needs to have a service Standard Operating Procedures for farmers. In addition, the local government officer needs to intensively provide service management training for auction market managers.
\end{abstract}

Keywords: chili, satisfaction, service, auction market

\begin{abstract}
Abstrak: Salah satu kelemahan pasar lelang cabai Sido Dadi adalah sistem tunda bayar kepada petani. Sistem ini dilakukan dengan menunggu pembayaran dari pedagang apabila cabai telah seluruhnya terjual. Keadaan tersebut berpotensi menyebabkan ketidakpuasan petani terhadap layanan dari pasar lelang. Tujuan dari penelitian ini adalah untuk mengetahui tingkat kepuasan petani anggota pasar lelang Sido Dadi dan mengetahui faktor yang mempengaruhinya. Penelitian ini dilakukan di Pasar Lelang Sido Dadi karena merupakan pasar lelang pertama di Kecamatan Galur Kabupaten Kulon Progo Provinsi Daerah Istimewa Yogyakarta. Jumlah sampel responden pada penelitian ini adalah 60 petani yang dipilih secara purposive sampling. Analisis yang digunakan adalah Customer Satisfaction Index (CSI) dan regresi. Hasil penelitian menunjukkan petani pengguna layanan pasar lelang Sido Dadi telah puas dengan layanan pasar lelang. Faktor yang mempengaruhi kepuasan petani antara lain usia, pendidikan, dan luas lahan. Hubungan kepuasan petani selaras dengan bertambahnya usia petani serta berkebalikan dengan tingkat pendidikan dan luas lahan petani. Pasar lelang Sido Dadi perlu untuk memanfaatkan dana iuran (fee) untuk melengkapi sarana prasarana serta pelatihan pengembangan sumber daya manusia. Pasar lelang juga perlu memiliki Standar Operasional Prosedur layanan bagi petani. Sedangkan dinas perlu secara intensif memberikan pelatihan manajemen layanan bagi pengelola pasar lelang.
\end{abstract}

Kata Kunci: cabai, kepuasan, layanan, pasar lelang 


\section{PENDAHULUAN}

Usahatani di lahan pasir pantai Provinsi Daerah Istimewa Yogyakarta (DIY) terdiri dari kombinasi tanaman hortikultura (bawang merah, cabai, dan terung) dan tanaman pangan (ketela pohon) serta peternakan (Widodo, 2015; Triyatmo et al., 2018). Dari beberapa komoditas, cabai mampu memberikan keuntungan paling besar bagi petani di lahan pasir pantai tersebut. Hal tersebut disebabkan keberadaan pasar lelang yang terbukti mampu membentuk harga jual cabai yang layak bagi petani (Nugroho et al., 2018).

Pasar lelang cabai di lahan pasir pantai mulai diinisiasi pada tahun 2003 (Raya, 2014). Pasar lelang ini muncul karena pemasaran cabai yang tidak menguntungkan bagi petani. Istiyanti (2010) menyatakan pemasaran cabai merah keriting di DIY menunjukkan petani memperoleh bagian hasil yang lebih rendah daripada pedagang pengecer. Hal tersebut juga diperkuat oleh Rum (2011) yang menunjukkan keuntungan terbesar pada pemasaran cabai diperoleh pedagang pengecer.

Pasar lelang merupakan lembaga pemasaran yang menyediakan pelayanan bagi petani untuk menjual hasil panen cabai merah kepada pedagang. Petani akan mudah memasarkan cabai merah karena dipertemukan langsung dengan pedagang. Pasar lelang memiliki banyak dampak positif, diantaranya menghubungkan langsung petani dengan konsumen, meningkatkan kesejahteraan petani, menciptakan pasar yang kompetitif, mengurangi biaya pemasaran, dan menjaga eksistensi positif keberadaan kelompok tani (Meulenberg, 1989; Perdana, 2016; Kaygisiz and Eken, 2018; Sogn-Grundvag et al., 2019).

Salah satu pasar lelang di lahan pasir pantai Provinsi DIY adalah Sido Dadi. Pasar lelang ini merupakan pasar lelang yang terletak di Kecamatan Galur dan dibentuk oleh Kelompok Tani Sido Dadi serta mengutamakan sistem lelang terbuka. Salah satu kelemahan pasar lelang Sido Dadi adalah sistem tunda bayar kepada petani. Sistem ini dilakukan dengan menunggu pembayaran dari pedagang apabila cabai telah seluruhnya terjual.

Keadaan tersebut berpotensi menyebabkan ketidakpuasan petani terhadap layanan dari pasar lelang. Dampak selanjutnya adalah petani tidak akan menjual cabai ke pasar lelang. Petani dapat saja memilih menjual langsung kepada pedagang agar mendapatkan dana penjualan secara tunai. Oleh karena itu, kepuasan petani perlu diukur dalam rangka pengembangan kualitas layanan pasar lelang Sido Dadi. Hasil penelitian Aydogdu et al. (2015) di Turki menunjukkan kepuasan petani sendiri dipengaruhi oleh usia, pengalaman usahatani, tingkat pendidikan, dan luas lahan

Penelitian ini memiliki kebaruan berupa objek penelitian anggota pasar lelang Sido Dadi yang belum pernah diteliti kepuasannya oleh peneliti lain. Sedangkan tujuan dari penelitian ini adalah untuk mengetahui tingkat kepuasan petani anggota pasar lelang Sidodadi Kecamatan Galur dan mengetahui faktor yang mempengaruhinya.

\section{METODE PENELITIAN}

Lokasi penelitian adalah di Pasar Lelang Sido Dadi, Desa Banaran, Kecamatan Galur, Kabupaten Kulon Progo. Dasar pemilihan lokasi ini yaitu purposive sampling dengan pertimbangan pasar lelang tersebut merupakan yang pertama didirikan di Kecamatan Galur dan banyak petani yang menjual produk ke pasar lelang tersebut.

Penelitian ini menggunakan data primer dengan jumlah sampel responden adalah 60 petani cabai pengguna jasa pasar lelang Sido Dadi. Pengambilan sampel dilakukan secara purposive sampling yakni petani yang menjadi anggota kelompok tani Sido Dadi. Hal tersebut disebabkan tidak semua petani peserta pasar lelang merupakan anggota kelompok tani. Metode untuk memperoleh data dari setiap responden adalah wawancara dengan kuesioner dan observasi.

Data yang diperoleh dari para responden akan dianalisis dengan Customer Satisfaction Index (CSI). Analisis ini digunakan untuk mengetahui tingkat kepuasan petani secara menyeluruh dengan melihat tingkat kepentingan dari setiap atribut. Untuk mengetahui besarnya CSI, maka dapat dilakukan langkah-langkah sebagai berikut (Wicaksana et al., 2013):

1. Menentukan Means Important Score MIS) dan Mean Satisfication Score (MSS)

Nilai ini didapat dari nilai rata-rata tingkat kepentingan dan nilai rata-rata kinerja tiap 
responden. $M I S=\frac{\sum_{i=1}^{n} Y_{i}}{n} \quad$ (1) dan

$$
M S S=\frac{\sum_{i=1}^{n} X_{i}}{n}
$$

Keterangan:

$n$ : Jumlah responden

$Y_{i}$ : nilai kepentingan atribut ke $i$

$X_{i}$ : nilai kinerja atribut ke $i$

2. Membuat Weight Factors (WF)

Bobot ini merupakan persentase nilai MIS per-atribut terhadap total MIS seluruh atribut.

$$
W F i=\frac{M I S_{i}}{\sum_{i=1}^{p} M I S_{i}} \times 100 \%
$$

Keterangan:

p : jumlah atribut kepentingan

$i \quad:$ atribut ke $i$

3. Membuat Weight Score (WS)

Bobot ini merupakan perkalian antara WF dengan MSS.

$$
\mathrm{WS}_{\mathrm{i}}=\mathrm{WF}_{\mathrm{i}} X \mathrm{MSS}_{\mathrm{i}}
$$

Total dari WS atribut ke-1 (a-1) hingga atribut terakhir (a-p) disebut dengan Weight Average Total (WAT).

$$
C S I=\frac{\sum_{i=1}^{p} W S_{i}}{H S} \times 100
$$

Keterangan:

$p=$ atribut ke $p$

$H S=$ skala maksimum yang digunakan

Hasil perhitungan CSI menunjukkan tingkat kepuasan yang dapat dikategorikan sesuai interval.

Tabel 1. Kriteria Customer Satisfaction Index (CSI)

\begin{tabular}{ll}
\hline Nilai CSI (\%) & Kriteria \\
\hline $0-34$ & Tidak Puas \\
$35-50$ & Kurang Puas \\
$51-65$ & Cukup Puas \\
$66-80$ & Puas \\
$81-100$ & Sangat Puas \\
\hline
\end{tabular}

Sumber: Wicaksana et al., 2013

Selanjutnya untuk mengetahui faktor yang mempengaruhi kepuasan petani terhadap layanan pasar lelang cabai Sido Dadi maka digunakan analisis regresi berganda. Langkah awal untuk melakukan analisis ini adalah dengan melakukan uji asumsi klasik yang meliputi uji normalitas, uji multikolinearitas, dan uji heteroskedastisitas (Widardjono, 2013).

Model persamaan yang digunakan dalam penelitian ini adalah sebagai berikut:

$Y_{i}=\beta_{0}+\beta_{1} X_{i, 1}+\beta_{2} X_{i, 2}+\beta_{3} X_{i, 3}+\beta_{4} X_{i, 4}+\varepsilon_{i}$

Keterangan:

$Y_{i}:$ kepuasan petani $(\%)$

$\beta_{0}:$ intersep

$\beta_{i}:$ koefisien regresi

$X_{1}$ : usia (tahun)

$X_{2}$ : tingkat pendidikan (tahun)

$X_{3}$ : pengalaman berusahatani cabai (tahun)

$X_{4}$ : luas lahan (ha)

$\varepsilon_{i}:$ error

\section{HASIL DAN PEMBAHASAN}

Pasar lelang Sido Dadi didirikan oleh kelompok tani Sido Dadi pada tahun 2012. Pasar lelang tersebut memiliki tujuan utama untuk menaikkan harga cabai di tingkat petani. Namun seiring berjalannya waktu, pasar lelang Sido Dadi mulai kehilangan kepercayaan dari petani. Hal tersebut disebabkan pedagang peserta lelang banyak yang memiliki hutang dan tidak segera dibayarkan kepada pasar lelang sehingga petani anggota pasar lelang mengalami kerugian. Dengan melihat keadaan tersebut, maka ketua kelompok tani memutuskan untuk mengelola pasar lelang secara mandiri.

Pasar lelang Sido Dadi sebenarnya hanya melelang cabai keriting, namun beberapa petani dapat menjual produk lain seperti kacang panjang, cabai rawit, dan terung. Produk tersebut biasanya akan dibeli oleh pedagang yang juga membeli cabai. Petani anggota peserta pasar lelang Sido Dadi utamanya adalah warga setempat. Namun, petani dari luar kecamatan Galur juga dapat menjadi peserta pasar lelang tersebut.

Pengelola pasar lelang Sido Dadi terdiri dari petugas dan pemilik. Petugas tersebut memiliki kewajiban untuk mengangkut cabai 
Tabel 2. Identitas petani peserta Pasar Lelang Sido Dadi berdasarkan umur, tingkat pendidikan, dan pengalaman

\begin{tabular}{lll}
\hline Kriteria & Jumlah (jiwa) & Persentase $(\%)$ \\
\hline Umur (tahun) & 55 & 91,67 \\
$>64$ & 5 & 8,33 \\
\hline Jumlah & 60 & 100,00 \\
\hline Tingkat Pendidikan (tahun) & & \\
\hline Tidak Sekolah & 5 & 8,33 \\
Tamat SD & 30 & 50,00 \\
Tamat SMP & 8 & 13,33 \\
Tamat SMA/SMK & 17 & 28,34 \\
\hline Jumlah & 60 & 100,00 \\
\hline Pengalaman Usahatani (tahun) & \\
\hline$<11$ & 13 & 21,67 \\
$11-30$ & 34 & 56,66 \\
$>30$ & 13 & 21,67 \\
\hline Jumlah & 60 & 100,00 \\
\hline
\end{tabular}

Sumber: Analisis Data Primer, 2020

dari petani, kemudian menyortir, dan menimbang berat cabai serta melakukan pencatatan administrasi mengenai kuantitas dan kualitas cabai tiap petani. Sementara itu, tugas pemilik pasar lelang yaitu berkomunikasi dengan pedagang, menerima uang dari pedagang, mengatur keuangan, mencatat berat cabai setiap petani, dan menyerahkan uang kepada petani.

Aktivitas pasar lelang Sido Dadi dilaksanakan setiap hari di rumah ketua kelompok tani dari pagi hari hingga sore hari. Petani mulai mengumpulkan cabai ke pasar lelang pada pagi hari sekitar pukul 09.00 WIB dan ditutup pada sore hari sekitar pukul 17.00 WIB. Pasca penutupan, para pedagang menawar harga cabai secara online. Harga yang disepakati adalah harga penawaran tertinggi yang diberikan pedagang. Aturan yang berlaku di Pasar Lelang Sido Dadi yaitu pedagang yang kalah dalam pelelangan juga dapat membeli cabai tersebut sesuai kesepakatan dengan pedagang pemenang.

Pada saat harga telah disepakati, maka selanjutnya pedagang mengirimkan pegawai untuk mengambil cabai di pasar lelang. Pedagang biasanya tidak langsung membayar pada saat pengambilan tersebut karena menunggu cabai terjual terlebih dahulu. Hal ini mendorong pemilik pasar lelang untuk aktif berkomunikasi dengan pedagang. Selain itu, pemilik pasar lelang juga meminjam uang dari bank agar petani dapat segera mendapatkan uang untuk melanjutkan usahatani maupun kehidupan sehari-hari. Petani dapat mengambil uang satu hari setelah proses lelang cabainya.

Responden dalam penelitian ini yaitu petani peserta pasar lelang Sidodadi di Trisik, Galur, Kulon Progo. Sampel yang diambil berjumlah 60 sampel dari populasi. Karakteristik petani berupa umur, tingkat pendidikan, pengalaman usahatani, luas lahan cabai, dan jumlah produksi cabai.

Petani peserta pasar lelang didominasi oleh petani berusia produktif dengan rata-rata 43 tahun. Hal tersebut menunjukkan masih banyak petani yang memiliki potensi untuk mengembangkan usahatani dengan baik. Petani yang berusia muda antara 35-45 tahun akan memiliki sikap adaptif terhadap teknologi baru serta inovatif dalam menjalankan usahatani cabai (Hamilton et al., 2015). Berdasarkan tingkat pendidikan, $50 \%$ dari peserta pasar lelang memiliki pendidikan terakhir yaitu Sekolah Dasar (SD). Hal tersebut menunjukkan bahwa masih banyak petani yang hanya memiliki pendidikan dasar sehingga perkembangan pola pikir lebih rendah 
dibandingkan dengan petani berpendidikan menengah maupun tinggi. Tingkat pendidikan memengaruhi kemampuan dan keterampilan dalam mengelola usahatani sehingga semakin tinggi tingkat pendidikan maka semakin mudah dalam menerima inovasi dan teknologi. Namun, pengetahuan mengenai pertanian belum tentu didapatkan pada pendidikan formal sehingga pendidikan non formal dibutuhkan untuk mengembangkan kemampuan petani. Sedangkan $56,66 \%$ petani memiliki pengalaman usahatani antara 11 sampai 30 tahun. Menurut Saptana et al. (2016) semakin lama pengalaman yang dimiliki petani maka semakin tinggi kemampuan untuk melakukan usahatani secara lebih baik. Petani yang berpengalaman mampu lebih efisien dalam menjalankan usahataninya, melakukan inovasi dan adopsi teknologi secara lebih maju, memiliki jaringan kerja (networking) yang lebih luas, dan memiliki kapabilitas manajerial yang lebih baik.

Petani peserta pasar lelang mayoritas memiliki luas lahan cabai rata-rata 0,2 ha dengan jumlah produksi cabai kurang dari 5 ton. Hal tersebut disebabkan banyaknya petani yang mendapatkan lahan dari warisan orang tua sehingga luas lahan cabai mayoritas hanya kecil. Selain itu, jumlah produksi juga dipengaruhi oleh perawatan yang dilakukan pada lahan seperti pemupukan dan pemberian pestisida dengan tepat.

Customer Satisfaction Index (CSI) merupakan metode yang digunakan untuk mengukur tingkat kepuasan petani pasar lelang Sido Dadi.

Nilai CSI petani pengguna layanan pasar lelang Sido Dadi sebesar 78,06\%. Nilai tersebut menunjukkan petani telah puas dengan layanan pasar lelang Sido Dadi. Pada dimensi tangibles, kelebihan utama pasar lelang adalah lokasi yang mudah diakses dan dijangkau. Lokasi pasar lelang terletak di lingkungan warga dan dekat dengan lahan cabai sehingga memudahkan petani untuk mengangkut cabai setelah panen dari lahan. Selain itu, pasar lelang juga didukung dengan tempat parkir serta tempat penampungan cabai yang luas. Pasar lelang memiliki dua ruang penampungan yang bersebelahan untuk meletakkan pasokan cabai dari petani. Saat jumlah produksi cabai sedikit, pasar lelang menampung cabai pada satu ruang penampungan saja. Sedangkan pada saat panen raya, maka pasar lelang menggunakan dua ruang penampungan cabai. Walaupun begitu, petani masih mengharapkan adanya peningkatan fasilitas ruang tunggu pasar lelang. Pada saat panen raya, semakin banyak petani yang ikut menjual cabai sehingga terkadang perlu antri untuk melakukan penimbangan cabai dan pencatatan di pasar lelang.

Oleh karena itu, harapan petani yaitu pasar lelang menyediakan kursi yang lebih banyak pada ruang tunggu. Selain itu, pada ruang tunggu terkadang terdapat beberapa barang yang tidak diperlukan seperti kardus, jaket, baju, sehingga membuat petani kurang nyaman. Selanjutnya pada dimensi responsiveness, kelebihan utama dari pasar lelang Sido Dadi adalah petugas pasar lelang memberikan informasi terbaru dengan cepat. Informasi yang disampaikan kepada petani yaitu informasi harga lelang dan penentuan hari tanam cabai. Penyebaran informasi tersebut dilakukan melalui grup whatsapp sehingga informasi didapatkan dengan cepat. Sedangkan bagi petani yang tidak memiliki telepon genggam, maka petugas pasar lelang akan memberikan informasi harga lelang kepada petani hanya saat bertemu di pasar lelang. Informasi lain adalah terkait budidaya tanaman yang didapatkan petani pada saat perkumpulan kelompok tani. Sementara itu, petani juga berharap pasar lelang mampu meningkatkan kinerja pada atribut responsiveness,

$\underline{\text { Tabel 3. Identitas petani peserta Pasar Lelang Sido Dadi berdasarkan jumlah produksi dan luas lahan cabai }}$

\begin{tabular}{llllll}
\hline \multirow{2}{*}{ Jumlah Produksi (ton) } & \multicolumn{2}{l}{ Luas Lahan (ha) } & Jumlah (jiwa) & Persentase (\%) \\
\cline { 2 - 5 } & $<0,5$ & $0,5-1,0$ & $>1,0$ & 56 & 93,34 \\
\hline$<5$ & 54 & 2 & 0 & 2 & 3,30 \\
$5-8$ & 0 & 2 & 0 & 2 & 3,30 \\
$>8$ & 0 & 1 & 1 & 60 & 100,00 \\
\hline Jumlah & 54 & 5 & 1 &
\end{tabular}

Sumber: Analisis Data Primer, 2020 
Agustin, R. D., Nugroho, A. D., Masyhuri: Kepuasan Petani Terhadap Layanan ...

Tabel 4. Customer Satisfaction Index (CSI) petani anggota Pasar Lelang Cabai Sido Dadi

\begin{tabular}{|c|c|c|c|c|c|c|}
\hline Dimensi & & Atribut & MIS & WF & MSS & WS \\
\hline \multirow{9}{*}{ Tangibles } & 1 & $\begin{array}{l}\text { Lokasi pasar lelang mudah diakses dan } \\
\text { dijangkau }\end{array}$ & 3,86 & 0,03 & 3,92 & 0,13 \\
\hline & 2 & $\begin{array}{l}\text { Pasar lelang memiliki tempat parkir yang } \\
\text { luas }\end{array}$ & 3,88 & 0,03 & 3,92 & 0,13 \\
\hline & 3 & $\begin{array}{l}\text { Pasar lelang luas dan memadai untuk } \\
\text { meletakkan pasokan cabai dari seluruh } \\
\text { peserta pasar lelang }\end{array}$ & 3,87 & 0,03 & 3,88 & 0,13 \\
\hline & 4 & $\begin{array}{l}\text { Pasar lelang bersih dan tidak ada sampah } \\
\text { berserakan }\end{array}$ & 3,91 & 0,03 & 3,93 & 0,13 \\
\hline & 5 & Fasilitas pasar lelang nyaman & 3,88 & 0,03 & 3,87 & 0,13 \\
\hline & 6 & $\begin{array}{l}\text { Adanya alat transportasi yang digunakan } \\
\text { untuk mengangkut cabai }\end{array}$ & 3,86 & 0,03 & 3,87 & 0,13 \\
\hline & 7 & $\begin{array}{l}\text { Alat timbang yang digunakan dalam } \\
\text { kondisi baik }\end{array}$ & 3,87 & 0,03 & 3,89 & 0,13 \\
\hline & 8 & $\begin{array}{l}\text { Petugas pasar lelang memiliki alat } \\
\text { komunikasi }\end{array}$ & 3,94 & 0,03 & 3,94 & 0,13 \\
\hline & 9 & $\begin{array}{l}\text { Petugas pasar lelang memiliki identitas } \\
\text { khusus (seragam, tanda nama, dll) }\end{array}$ & 3,85 & 0,03 & 3,88 & 0,13 \\
\hline \multirow{5}{*}{$\begin{array}{l}\text { Responsive } \\
\text { ness }\end{array}$} & 10 & $\begin{array}{l}\text { Petugas pasar lelang cepat dalam melayani } \\
\text { petani }\end{array}$ & 3,89 & 0,03 & 3,90 & 0,13 \\
\hline & 11 & $\begin{array}{l}\text { Petugas pasar lelang tanggap dalam } \\
\text { memenuhi kebutuhan petani }\end{array}$ & 3,91 & 0,03 & 3,92 & 0,13 \\
\hline & 12 & $\begin{array}{l}\text { Petugas pasar lelang tanggap dalam } \\
\text { mengatasi masalah }\end{array}$ & 3,90 & 0,03 & 3,91 & 0,13 \\
\hline & 13 & $\begin{array}{l}\text { Petugas pasar lelang membantu } \\
\text { pengangkutan cabai dengan tanggap }\end{array}$ & 3,92 & 0,03 & 3,87 & 0,13 \\
\hline & 14 & $\begin{array}{l}\text { Petugas pasar lelang memberikan informasi } \\
\text { terbaru dengan cepat }\end{array}$ & 3,86 & 0,03 & 3,88 & 0,13 \\
\hline \multirow{6}{*}{ Reliability } & 15 & $\begin{array}{l}\text { Petugas pasar lelang memberikan informasi } \\
\text { dengan jelas }\end{array}$ & 3,92 & 0,03 & 3,94 & 0,13 \\
\hline & 16 & $\begin{array}{l}\text { Petani dapat dengan mudah menjadi peserta } \\
\text { pasar lelang }\end{array}$ & 3,91 & 0,03 & 3,93 & 0,13 \\
\hline & 17 & $\begin{array}{l}\text { Petugas pasar lelang dapat dengan mudah } \\
\text { dihubungi melalui telepon }\end{array}$ & 3,91 & 0,03 & 3,93 & 0,13 \\
\hline & 18 & $\begin{array}{l}\text { Petugas pasar lelang melakukan pencatatan } \\
\text { dengan teliti dan jelas }\end{array}$ & 3,94 & 0,03 & 3,90 & 0,13 \\
\hline & 19 & $\begin{array}{l}\text { Total uang dari penjualan cabai setiap } \\
\text { petani sesuai dengan perhitungan }\end{array}$ & 3,95 & 0,03 & 3,90 & 0,13 \\
\hline & 20 & $\begin{array}{l}\text { Jadwal jam buka dan tutup pasar lelang } \\
\text { tepat waktu }\end{array}$ & 3,89 & 0,03 & 3,90 & 0,13 \\
\hline \multirow{6}{*}{ Assurance } & 21 & $\begin{array}{l}\text { Pasar lelang mampu menampung } \\
\text { berapapun cabai yang dihasilkan petani }\end{array}$ & 3,91 & 0,03 & 3,92 & 0,13 \\
\hline & 22 & $\begin{array}{l}\text { Petugas pasar lelang memberikan } \\
\text { pelayanan dengan sopan }\end{array}$ & 3,91 & 0,03 & 3,94 & 0,13 \\
\hline & 23 & Petugas pasar lelang dapat dipercaya & 3,93 & 0,03 & 3,94 & 0,13 \\
\hline & 24 & $\begin{array}{l}\text { Pembayaran dari penjualan cabai dilakukan } \\
\text { tepat waktu }\end{array}$ & 3,93 & 0,03 & 3,94 & 0,13 \\
\hline & 25 & $\begin{array}{l}\text { Biaya jasa yang ditetapkan pasar lelang } \\
\text { wajar }\end{array}$ & 3,88 & 0,03 & 3,93 & 0,13 \\
\hline & 26 & Keakuratan timbangan & 3,94 & 0,03 & 3,88 & 0,13 \\
\hline \multirow{7}{*}{ Empathy } & 27 & $\begin{array}{l}\text { Petugas pasar lelang bersedia membantu } \\
\text { tanpa diminta }\end{array}$ & 3,94 & 0,03 & 3,91 & 0,13 \\
\hline & 28 & $\begin{array}{l}\text { Petugas pasar lelang bersedia untuk } \\
\text { menghargai dan melayani } \\
\text { mengutamakan kebutuhan petani }\end{array}$ & 3,91 & 0,03 & 3,92 & 0,13 \\
\hline & 29 & $\begin{array}{l}\text { Petugas pasar lelang bersedia terbuka dan } \\
\text { jujur dalam memberikan pelayanan } \\
\text { informasi }\end{array}$ & 3,92 & 0,03 & 3,93 & 0,13 \\
\hline & 30 & $\begin{array}{l}\text { Petugas pasar lelang memberikan bantuan } \\
\text { subsidi melalui kelompok tani (pupuk, } \\
\text { benih, bibit, dll) }\end{array}$ & 3,89 & 0,03 & 3,90 & 0,13 \\
\hline & & Jumlah & 117,08 & 1,00 & & \multirow{2}{*}{3,90} \\
\hline & & WT & & & & \\
\hline & & $\operatorname{CSI}(\%)$ & & & & 78,06 \\
\hline
\end{tabular}

Sumber: Analisis Data Primer, 2020 
terutama daya tanggap petugas untuk membantu pengangkutan cabai. Pasar lelang sebenarnya menyediakan jasa angkut berdasarkan panggilan telepon dari petani. Namun, petani harus menunggu lama proses pengangkutan tersebut. Hal tersebut disebabkan petugas melakukan proses pengangkutan setiap lima hari sekali. Dampak dari pengangkutan yang lambat ini adalah antrian yang tidak menentu sehingga beberapa petani memilih membawa produksi cabai dengan kendaraan pribadi.

Kelebihan utama pasar lelang pada dimensi reliability adalah kemudahan petani untuk menghubungi petugas pasar lelang melalui telepon genggam. Petani yang tidak memiliki telepon genggam biasanya meminta tolong petani lain atau keluarganya untuk menghubungi petugas. Kelebihan lain pasar lelang ini adalah kemudahan petani menjadi peserta pasar lelang. Pada waktu awal berdirinya pasar lelang, petani harus mendaftar dan iuran sebesar Rp. 500.000,00. Iuran tersebut digunakan sebagai modal pembangunan pasar lelang. Saat ini, petani tidak dipungut biaya apabila ingin menjadi anggota pasar lelang. Petani cukup membawa hasil panen cabai ke pasar lelang. Namun,saat ini petani harus membayar fee sebesar Rp 500 dari tiap kilogram cabai yang terjual di pasar lelang. Dana tesebut akan digunakan sebagai gaji bagi pemilik dan pengelola pasar lelang. Sementara itu, peserta pasar lelang dapat berasal dari luar kelompok tani. Harapan petani yang belum terpenuhi pada dimensi ini adalah ketelitian petugas pasar lelang dalam melakukan pencatatan dan perhitungan total uang dari penjualan cabai. Petugas pasar lelang sebenarnya telah melakukan pencatatan jumlah cabai setiap petani yang dijual ke pasar lelang. Namun terkadang ada petugas yang tulisannya kurang jelas ataupun kurang teliti dalam mencatat sehingga penjumlahan berat karung pernah tidak sesuai dengan kondisi faktual. Sementara itu, dalam penerimaan uang hasil penjualan cabai, petani diberikan kertas yang terdapat rincian harga lelang cabai, jumlah berat cabai yang dijual dan total uang yang diterima pada hari tersebut. Namun, petani pernah mendapatkan total uang yang tidak sesuai dengan yang tertulis pada kertas. Hal tersebut disebabkan petugas tidak teliti dalam menghitung uang. Walaupun begitu, petani masih memaklumi hal tersebut karena pasar lelang memegang uang milik banyak orang.

Pada dimensi assurance, petani menganggap petugas pasar lelang memberikan pelayanan dengan sopan dan dapat dipercaya. Petugas pasar lelang sampai saat ini belum pernah menyembunyikan uang atau kehilangan uang. Poin tersebut yang membuat pasar lelang dapat dipercaya oleh petani. Sedangkan, harapan petani yang belum terpenuhi pada dimensi ini adalah keakuratan timbangan. Hal tersebut disebabkan timbangan di pasar lelang pernah tidak akurat karena tidak dikalibrasi secara berkala. Meskipun perbedaannya hanya sedikit, hal tersebut dapat merugikan petani maupun pasar lelang.

Dimensi terakhir adalah emphaty dimana kelebihannya adalah petugas pasar lelang bersedia untuk menghargai dan melayani serta mengutamakan kebutuhan petani. Pasar lelang selalu memperhatikan kebutuhan petani dengan berani meminjam uang ke bank agar petani segera mendapatkan uang hasil penjualan cabai. Petugas pasar lelang juga terbuka dan jujur dalam penyampaian informasi, khususnya informasi harga jual lelang. Pada sisi lain, petani masih berharap petugas pasar lelang bersedia membantu tanpa diminta. Beberapa petani yang mengangkut cabai dengan sepeda motor akan membutuhkan bantuan petugas saat menurunkan karung. Namun, petugas perlu diminta tolong terlebih dahulu untuk menurunkan muatan tersebut.

Selanjutnya dilakukan analisis regresi untuk mengetahui faktor yang mempengaruhi kepuasan petani terhadap layanan pasar lelang Sido Dadi. Tahapan pertama yang dilakukan pada analisis regresi adalah uji asumsi klasik. Hal tersebut dilakukan agar hasil estimasi yang didapatkan dari analisis regresi bersifat Best Linear Unbiased Estimator (BLUE). Uji asumsi klasik yang pertama adalah uji normalitas. Metode yang digunakan pada penelitian ini yaitu uji normalitas KolmogorovSmirnov.

Berdasarkan uji normalitas dapat diketahui bahwa nilai signifikansi yaitu 0,200 atau lebih besar dari alpha $(0,05)$. Hal tersebut menunjukkan bahwa data memiliki nilai residual yang berdistribusi normal.

Selanjutnya dilakukan

uji multikolinearitas untuk melihat hubungan antar variabel bebas. 
Tabel 5. Hasil Uji Normalitas Kolmogorov-Smirnov

\begin{tabular}{|c|c|c|}
\hline & & $\begin{array}{l}\text { Unstandardized } \\
\text { Residual }\end{array}$ \\
\hline \multicolumn{2}{|l|}{$\mathrm{N}$} & 60 \\
\hline \multirow{2}{*}{$\begin{array}{l}\text { Normal } \\
\text { Parameters }^{\mathrm{a}, \mathrm{b}}\end{array}$} & Mean & 0,0000000 \\
\hline & Std. Deviation & 0,27465767 \\
\hline \multirow{3}{*}{$\begin{array}{l}\text { Most Extreme } \\
\text { Differences }\end{array}$} & Absolute & 0,101 \\
\hline & Positive & 0,101 \\
\hline & Negative & $-0,074$ \\
\hline \multicolumn{2}{|c|}{ Test Statistic } & 0,101 \\
\hline \multicolumn{2}{|c|}{ Asymp. Sig. (2-tailed) } & 0,200 \\
\hline
\end{tabular}

Pada penelitian ini, uji multikolinearitas pada model regresi dideteksi dengan melihat nilai Variance Inflation Factor (VIF) pada masing-masing variabel. Gejala multikolinearitas ditunjukkan dengan nilai VIF lebih dari 10.

Tabel 6. Hasil Uji Multikolinearitas

\begin{tabular}{lll}
\hline No. & Variabel & VIF \\
\hline 1. & Umur (X1) & 4,912 \\
2. & Tingkat pendidikan (X2) & 2,174 \\
3. & Pengalaman berusahatani (X3) & 4,891 \\
4. & Luas lahan (X4) & 1,060 \\
\hline
\end{tabular}

Sumber: Analisis Data Primer, 2020

Tabel 7. Hasil Uji Heteroskedastisitas

\begin{tabular}{lll}
\hline No. & Variabel & Sig. \\
\hline 1. & Umur (X1) & 0,435 \\
2. & Tingkat pendidikan (X2) & 0,650 \\
3. & Pengalaman berusahatani (X3) & 0,965 \\
4. & Luas lahan (X4) & 0,805 \\
\end{tabular}

Sumber: Analisis Data Primer, 2020

Empat variabel independen memiliki nilai VIF di bawah 10 sehingga dapat disimpulkan pada model regresi tidak terdapat gejala multikolinearitas.Tahapan terakhir dari uji asumsi klasik adalah pengujian heteroskedastisitas yang ditunjukkan dengan ada tidaknya ketidaksamaan varian dari residual pada model regresi linear. Metode yang digunakan pada penelitian ini yaitu metode Glejser.

Nilai signifikansi residual lebih dari 0,05 maka model regresi tidak terdapat masalah heteroskedastisitas. Dengan begitu, data yang digunakan pada model regresi telah memenuhi asumsi klasik sehingga dapat menghasilkan hasil estimasi yang terbaik. Analisis regresi dilakukan untuk mengetahui pengaruh variabel independen (umur, tingkat pendidikan, pengalaman berusahatani, dan luas lahan) terhadap variabel dependen (kepuasan).

Nilai Adjusted $\mathbf{R}^{2}$ adalah 0,315 sehingga dapat disimpulkan bahwa variasi variabel independen (umur, tingkat pendidikan, pengalaman berusahatani, dan luas lahan) dapat menjelaskan variasi variabel dependen (kepuasan) sebesar 31,5\% dan sisanya sebesar $68,5 \%$ dijelaskan oleh variabel di luar model. Dari hasil analisis regresi linear berganda juga diperoleh nilai $\mathrm{F}$ hitung sebesar 7,770 dan $\mathrm{F}$ tabel sebesar 2,770. Hasil tersebut menunjukkan bahwa $\mathrm{F}$ hitung lebih besar dari $\mathrm{F}$ tabel, maka dapat disimpulkan variabel umur $\left(\mathrm{X}_{1}\right)$, tingkat pendidikan $\left(\mathrm{X}_{2}\right)$, pengalaman usahtani $\left(\mathrm{X}_{3}\right)$, dan luas lahan $\left(\mathrm{X}_{4}\right)$ secara bersama-sama berpengaruhi signifikan terhadap kepuasan petani.

Pengaruh masing-masing variabel independen terhadap variabel dependen. Variabel umur $\left(\mathrm{X}_{1}\right)$ memiliki nilai probabilitas $\mathrm{t}$ sebesar 0,044 lebih kecil dari alpha 0,05 sehingga umur petani memberikan pengaruh yang signifikan terhadap kepuasan petani.

Hal ini sesuai dengan penelitian Jozias et al. (2020) yang menyatakan semakin bertambah usia seseorang maka semakin tinggi kemungkinan untuk memilih atau loyal terhadap sebuah produk atau jasa. Nilai koefisien regresi variabel $X_{1}$ yaitu 0,014. Pada setiap penambahan umur sebanyak 1 tahun maka kepuasan petani meningkat sebesar 0,014\%. Pada penelitian ini, $96,71 \%$ petani berusia produktif dengan rata-rata 43 tahun sehingga memiliki harapan tinggi untuk memenuhi kebutuhan hidupnya. Kondisi tersebut sudah selaras dengan layanan pasar lelang yang cukup baik, terutama mampu memberikan harga yang layak bagi petani. Oleh karena itu, semakin meningkat usia petani maka semakin puas terhadap layanan Pasar Lelang Sido Dadi.

Tingkat pendidikan $\left(\mathrm{X}_{2}\right)$ memiliki nilai probabilitas $\mathrm{t}$ sebesar 0,027 . Nilai tersebut kurang dari alpha 0,05 sehingga H0 ditolak. Pada tingkat kepercayaan 95\%, tingkat pendidikan memberikan pengaruh yang signifikan terhadap kepuasan petani. Nilai koefisien regresi variabel ini yaitu $-0,036$. Pada setiap peningkatan tingkat pendidikan petani sebanyak 1 tahun maka kepuasan petani menurun sebesar $0,036 \%$. Tingkat pendidikan yang berpengaruh negatif dapat terjadi karena 
Tabel 8. Hasil analisis Regresi faktor-faktor yang memengaruhi kepuasan petani terhadap layanan Pasar Lelang Sido Dadi

\begin{tabular}{|c|c|c|c|c|c|c|c|}
\hline No. & Variabel & $\begin{array}{l}\text { Tanda } \\
\text { Harapan }\end{array}$ & $\begin{array}{l}\text { Koef. Regresi } \\
\text { (B) }\end{array}$ & t-tabel & t-hitung & Sig. & Ket. \\
\hline 1. & Konstanta & $+/-$ & -0.077 & 1,673 & $-0,252$ & 0,639 & ns \\
\hline 2. & $\operatorname{Umur}\left(\mathrm{X}_{1}\right)$ & + & 0,014 & 1,673 & 2,060 & 0,044 & $*$ \\
\hline 3. & Tingkat pendidikan $\left(\mathrm{X}_{2}\right)$ & - & $-0,036$ & 1,673 & $-2,270$ & 0,027 & $*$ \\
\hline 4. & Pengalaman berusahatani $\left(\mathrm{X}_{3}\right)$ & + & $-0,007$ & 1,673 & $-0,992$ & 0,326 & ns \\
\hline 5. & Luas lahan $\left(\mathrm{X}_{4}\right)$ & + & $-0,443$ & 1,673 & $-2,606$ & 0,012 & $*$ \\
\hline \multicolumn{2}{|c|}{ Adjusted $\mathrm{R}^{2}$} & 0,315 & & & & & \\
\hline \multicolumn{2}{|c|}{ F hitung } & 7,770 & & & & & \\
\hline \multicolumn{2}{|c|}{ F table } & 2,770 & & & & & \\
\hline
\end{tabular}

Keterangan: *signifikansi pada tingkat kepercayaan 95\%; ns: non signifikan

Sumber: Analisis Data Primer, 2020

semakin tinggi pendidikan maka petani akan termotivasi untuk menerima dan mencari informasi dengan lebih baik. Dari informasi yang didapatkan, rata-rata maka sekolah petani adalah 10,4 tahun dan terus berupaya agar penjualannya lebih menguntungkan sehingga dapat dimungkinkan petani tidak puas dengan kualitas layanan pasar lelang pada saat ini. Hubungan ini juga diperkuat oleh Aydogdu et al. (2015) yang melakukan penelitian mengenai faktor-faktor yang mempengaruhi kepuasan petani terhadap Asosiasi Pengguna Air (WUA) di Turki. Ternyata semakin tinggi tingkat pendidikan maka kepuasan petani terhadap WUA semakin turun.

Pengalaman berusahatani $\left(\mathrm{X}_{3}\right)$ memiliki nilai probabilitas $t$ sebesar 0,326 . Nilai tersebut lebih dari alpha 0,05 sehingga $\mathrm{H} 0$ gagal ditolak. Hasil tersebut sesuai dengan penelitian Salju dan Lukman (2018) yang menunjukkan tidak selalu pengalaman akan memberikan pengaruh signifikan terhadap variabel dependen. Sementara dalam penelitian ini, pengalaman petani sangat bervariasi sehingga tidak berpengaruh signifikan terhadap kepuasan petani. Beberapa petani merupakan pemuda dan pendatang sehingga memiliki pengalaman usahatani yang bervariasi. Pendatang merupakan seseorang yang bukan penduduk asli wilayah setempat yang dapat disebabkan oleh adanya migrasi ke wilayah tersebut. Selain itu, terdapat petani yang berawal dari alih profesi sehingga kurang memiliki pengalaman berusahatani.

Luas lahan $\left(\mathrm{X}_{4}\right)$ memiliki nilai probabilitas $\mathrm{t}$ sebesar 0,012 . Nilai tersebut kurang dari alpha 0,05 sehingga H0 ditolak. Pada tingkat kepercayaan $95 \%$ luas lahan memberikan pengaruh yang signifikan terhadap kepuasan petani. Nilai koefisien regresi variabel ini yaitu -0,443. Pada setiap peningkatan luas lahan sebanyak 1 ha maka kepuasan petani menurun sebesar 0,443\%. Hasil penelitian ini menunjukkan bahwa semakin luas lahan maka petani semakin tidak puas. Pada lahan yang luas, petani memiliki produksi cabai dalam jumlah besar sehingga petani memiliki kemungkinan untuk memilih saluran pemasaran yang lebih menguntungkan untuk memasarkan produksi cabai (Purwasih et al., 2020). Kondisi ini membuat petani akan membandingkan antar saluran pemasaran tersebut sehingga kualitas layanan pasar lelang memiliki kemungkinan tidak memuaskan petani.

\section{KESIMPULAN}

Petani anggota pasar lelang Sido Dadi telah puas dengan layanan pasar lelang. Walaupun begitu, masih ada beberapa harapan petani untuk pengembangan pasar lelang, diantaranya peningkatan fasilitas ruang tunggu dan ketelitian timbangan di pasar lelang. peningkatan daya tanggap petugas untuk membantu pengangkutan cabai, dan peningkatan ketelitian petugas pasar lelang dalam melakukan pencatatan dan perhitungan. Faktor utama yang mempengaruhi kepuasan petani terhadap layanan pasar lelang Sido Dadi adalah umur, tingkat pendidikan, dan luas lahan. Hubungan kepuasan petani selaras dengan bertambahnya usia petani serta berkebalikan dengan tingkat pendidikan dan luas lahan petani.

Dalam rangka pengembangannya, pasar lelang Sido Dadi perlu untuk memanfaatkan dana iuran (fee) dari petani untuk melengkapi 
sarana ruang tunggu dan timbangan yang modern serta pelatihan pengembangan sumber daya manusia, terutama administrasi dan manajemen layanan pasar lelang. Pasar lelang juga perlu memiliki SOP dalam rangka memberi kan layanan terbaik bagi petani. Peran serta dinas sangat diperlukan dalam rangka optimalisasi layanan pasar lelang melalui pelatihan manajemen bagi pengelola pasar lelang.

\section{DAFTAR PUSTAKA}

qqwAydogdu, M. H., Yenigun, K., \& Aydogdu, M. (2015). Factors affecting farmers' satisfaction from Water Users Association in The Harran Plain-GAP Region, Turkey. Journal of Agricultural Science and Technology, 17(December), 1669-1684.

Hamilton, W., Bosworth, G., \& Ruto, E. (2015). Entrepreneurial younger farmers and the "Young Farmer Problem" in England. Agriculture \& Forestry, 04(02), 105-110. https://doi.org/10.17707/AgricultForest.6 1.4.05.

Istiyanti, E. (2010). Efisiensi pemasaran cabai merah keriting di Kecamatan Ngemplak Kabupaten Sleman. Jurnal Pertanian Mapeta, 12(2), 116-124.

Jozias, V., Timisela, N. R., \& Lawalata, M. (2020). Analisis segmentasi pasar sayuran organik di Pulau Saparua Kabupaten Maluku Tengah. Jurnal Sosial Ekonomi Pertanian dan Agribisnis SEPA, 17(1), 72-82. https://doi.org/10.20 961/ sepa.v1 7i1.42910.

Kaygisiz, F., \& Eken, M. A. (2018). Research on determination of fish marketing margins in Istanbul Province of Turkey. Turkish Journal of Fisheries and Aquatic Sciences, 18, 801-807. https://doi.org/10.4194/1303-2712v18_6_06.

Meulenberg, M. T. G. (1989). Horticultural Auctions in the Netherlands: A Transition from "Price Discovery" institution to "Marketing" institution.
Journal of International Food and Agribusiness Marketing, 1(3-4), 139165. https://doi.org/10.1300/J047v01n03 -08.

Nugroho, A. D., Prasada, I. Y., Kirana, S., Anggrasari, H., \& Sari, P. N. (2018). Rantai nilai cabai di lahan pasir pantai Kabupaten Kulon Progo. Economics Development Analysis Journal, 7(4): 458-467. https://doi.org/10.15294/edaj.v $7 \mathrm{i} 4.25013$.

Perdana, A. S. (2016). Pemberdayaan kelompok tani melalui pasar lelang sebagai solusi mewujudkan kedinamisan kesejahteraan petani. VIGOR: Jurnal Ilmu Pertanian dan Subtropika, 1(1), 5263. https://doi.org/10.31002/vigor.v1i1. 317.

Purwasih, R., Bahtera, N. I., \& Yulia. (2020). Determinan produksi cabai merah di Kabupaten Bangka Tengah. Jurnal Sosial Ekonomi Pertanian dan Agribisnis SEPA, 17(1), 49-54. https://doi.org/10.20961/se pa.v17i1.41166.

Raya, A. B. (2014). A Comparison of the function of leader-member exchange in two neighboring farmer groups in a sandy land area in Yogyakarta Province, Indonesia. Asian Social Science, 10(12), 21-34. https://doi.org/10.5539/ass.v10n $12 \mathrm{p} 21$.

Rum, M. (2011). Analisis marjin pemasaran dan sensitivitas cabai besar di Kabupaten Malang. Embryo, 8(2), 133-141.

Salju, \& Lukman, M. (2018). Pengaruh motivasi dan pengalaman kerja terhadap produktivitas kerja karyawan PT. Comindo Mitra Sulawesi Cabang Palopo. Jurnal Manajemen, 4(1), 1-7.

Saptana, N., Daryanto, A., Daryanto, H. K., \& Kuntjoro, N. (2016). Analisis efisiensi teknis produksi usahatani cabai merah besar dan perilaku petani dalam menghadapi risiko. Jurnal Agro Ekonomi, 28(2), 153-188. https://doi.org/10.21082/jae.v28n2.2010. 
Sogn-Grundvåg, G., Zhang, D., \& Iversen, A. (2019). Large buyers at a fish auction: The case of the Norwegian Pelagic Auction. Marine Policy, 104, 232-238. https://doi. org/10.1016/j.marpol. 2018. 06.011 .

Triyatmo, B., Rustadi., \& Priyono, S. B. (2018). Characteristics and environmental carrying capacities of coastal area in Yogyakarta Special Region for aquaculture. IOP Conference Series: Earth and Environmental Science, 139,012007. https://doi.org/ 10.1088/1755-1315/139/1/012007.

Wicaksana, B. E., Muhaimin, A. W., \&
Koestiono, D. (2013). Analisis sikap dan kepuasan petani dalam menggunakan benih kentang bersertifikat (Solanum tuberosum L.) (Kasus di Kecamatan Bumiaji Kota Batu). Habitat, 24(3), 184193.

Widardjono, A. (2013). Ekonometrika: Pengantar dan Aplikasinya. Yogyakarta: UPP STIM YKPN.

Widodo, A.S. 2015. The Influence of risk production level toward optimization conservation farming at coastal land in Yogyakarta Special Province, Indonesia. Proceedings ICoA Conference, 67-71. 